\title{
Marketing Theory in Global Business Context
}

\subsection{Global Strategy and Marketing in Emerging Countries}

Advancements in emerging countries present new market opportunities for Japanese corporations; however, to do so, they must confront the threats posed by local companies playing catch up by moving from a "build it and it will sell" product model to a customer value model that maximizes the value to the customer. To overcome this dilemma, companies must understand markets in these emerging countries (i.e., customer needs) at product- and service-planning levels, accordingly design products and services that maximize value to the target customers, and create channels to get these products and services to the consumers. These activities comprise marketing activities.

Compared with their counterparts in the West, Japanese companies have little understanding of marketing activities. Japanese companies heavily emphasize sales. In Europe and the US, marketing and sales denote different functions, but in Japan, they are often mixed. The Japanese word for sales, eigyou, refers to activities that increase the revenue from existing products, for example, a sales representative visiting customers in an effort to book orders. Marketing, on the other hand, is based on a principle that encompasses a strategic philosophy that determines the types of customers - including new customers-a company should target, and the types of products that should be developed to increase customer satisfaction. With the "build it and it will sell" concept, marketing is not essential, and sales activities alone are sufficient. However, a customer value model that designs products and services that maximize customer value requires a company to grasp the needs of its customers and prioritize marketing activities.

Marketing activities can be divided into two main steps. The first is a strategic step of segmentation of market information by customer type, and the selection of a target customer group. In taking such a step to facilitate global businesses, the CAGE framework explained in Chap. 2 is valuable to analyze the differences between a company's home country and other countries. A company will have a 
deep understanding of the history of its own country, and the CAGE framework will provide hints to deepen a company's understanding of other target countries. A company must gather important points from the CAGE framework to develop marketing strategies and conduct a more detailed analysis using market survey data and various types of statistical data.

The second step moves into execution with the careful consideration and implementation of product, price, place, and promotion based on the aforementioned strategies. These elements are collectively called the 4Ps of marketing. For example, in Shiseido's marketing in China, covered in the next chapter, the company switched its brand names and distribution channels when selling its products to high-income and middle-income consumers. Companies must, thus, select the right target customers and 4P marketing mix on the basis of a marketing strategy, and execute the plan accordingly.

In this chapter, we discuss the important concept of the "good enough market" as we examine marketing strategies in emerging countries. The average income levels in these countries are lower than those in developed countries; however, they constitute a rapidly expanding middle class who wish to own low-cost products with a certain level of quality. This is called the "volume zone." Reducing a product's functionality to what is required by customers in an effort to minimize costs is one way in which companies can develop products for particular markets, thereby enabling high returns in the huge markets within emerging countries. In this chapter, we discuss the strategy for the "good enough" product market in both China and India as we analyze the markets in each country.

We conclude this chapter by examining the bottom of the pyramid strategy or BOP. Of the entire global population of approximately six billion people, four billion have an annual income of less than USD 1,500. This amounts to living on an income of just a few dollars per day. BOP businesses require strategies to target this lowest level of the population pyramid. In India, consumer packaged goods (CPG) manufacturer Unilever and the micro-financing giant ICICI Bank both target the BOP layer. Among Japanese companies, Ajinomoto's work on improving nutrition in Ghana is one such example. BOP has been the focus of attention for companies thinking about their global business; it is a business model that provides valuable hints for companies' business in emerging countries, such as relationships with local governments and nongovernmental organizations (NGOs).

\subsection{Steps in Marketing Strategy}

Using SWOT analysis described in Chap. 2 to clarify the internal management resources of a company (its strengths and weaknesses) and the external management environment (opportunities and threats), steps in marketing strategy can help determine a company's direction as it invests in new management resources. In this step, companies create management strategies; however, it requires a more detailed analysis to move to the execution phase of specific product development and distribution channel creation. 
Table 9.1 Product and market matrix

\begin{tabular}{l|l|l}
\hline \multirow{2}{*}{ Product } & Market & New \\
\cline { 2 - 3 } & Existing & (2) Market development \\
\hline Existing & (1) Market penetration & (4) Diversification \\
\hline New & (3) Product development &
\end{tabular}

We now introduce Ansoff's product market matrix, a valuable tool to create strategies on the basis of market and customer relationships. The matrix divides both products and markets into the "existing" and "new," and indicates the direction in which companies can achieve growth. The first area is "market penetration," in which companies target existing markets with existing products. Other areas to which a company's business domain may expand to include "product development," in which a company develops new products for existing markets, "market development," in which a company brings existing products to new markets, and "diversification," in which a company pioneers new products for new markets (Table 9.1).

An implementation of the product/market matrix to a global business, considering their entry into new countries or regions, naturally leads to "market development" or "diversification" as options to companies. In Chap. 2, we discussed Ghemawat's CAGE frameworks and the AAA as frameworks used when considering global strategy. According to the CAGE framework, the distance between a company's home country and a target country can be considered from four different aspects: cultural, administrative, geographical, and economic. Using AAA, companies can select the optimal direction from among adaptation (to the target country), aggregation (across the globe), and arbitrage (which takes advantage of distances). Aggregation refers to market development that uses existing products to go after new markets, while adaptation corresponds to diversification, in which product development is conducted to match new market conditions. An example of arbitrage is the offshore development of software in countries with low wages. Arbitrage is a methodology of supplying products and services, and it is not directly related to marketing, which is related with customer interactions.

Gathering and analyzing market information, followed by validating the consistency of that information with a company's products, are critical in setting marketing strategy. In the process of global business expansion, data collection and analysis are particularly important. Choosing to develop new markets with existing products or diversify markets through new product development will depend on the target market's acceptability of a company's products. Note that large countries such as China and India comprise a range of markets. The CAGE framework in Chap. 2 is used in this chapter on a country-by-country basis, but, for example, China shows vast regional divergence in living conditions in the country, with regions along the coast showing a significantly different level of economic development compared with western regions. English and Hindi are the two official languages spoken in India, even though each region has its own dialect, with the company comprising more than 20 quasi-official languages. Each Indian state has an independent bureaucracy, with tariffs levied on the distribution of goods across state borders and 
Table 9.2 Example of market segmentation

\begin{tabular}{l|l}
\hline Variables & Segment example \\
\hline 1. Geographical variables & Kanto, Kansai \\
\hline Region & Cold/hot, seasons \\
\hline Climate & Urban, suburban, rural \\
\hline Population density & \\
\hline 2. Demographic variables & Teens, youth, middle-aged, seniors \\
\hline Age & Male, female \\
\hline Gender & Married, unmarried \\
\hline Family composition & +JPY 30 million \\
\hline Income & Blue-collar, white-collar \\
\hline Work & \\
\hline 3. Psychological variables & Enjoys sports, outdoors \\
\hline Lifestyle & Enjoys new things, conservative \\
\hline Personality & \\
\hline 4. Behavioral variables & Economical, functional, prestige \\
\hline Sought-after benefits & Non-user, light user, heavy user \\
\hline Usage & \\
\hline Source: Adapted from Diamond Inc. (2002) chart on p. 55 &
\end{tabular}

different regulations imposed on companies. Thus, we see that distances exist among various aspects of the CAGE framework even within a single country, and each country may have a variety of markets.

Therefore, a marketing strategy must be selected by first segmenting and then targeting markets. Market segmentation can be conducted in many ways, as indicated in Table 9.2. The first type is segmentation using geographical variables. Climate and lifestyle vary by area. The same applies to language, as seen in the case of India. Attributes of population segmentation such as gender, age, or income levels are also important. For products that target the youth or the elderly, a change in specifications may be necessary. In addition, companies should consider segmentation by household income levels when considering the establishment of businesses in emerging countries. The "good enough" product market in China and India, explained later in greater detail, targets the rapidly growing middle classes in these countries. When examining China's disposable income distribution, it is observed that the top $10 \%$ have an average annual income of approximately USD 32,000, while the lower $10 \%$ have an average income of only USD 950 - a disparity of more than 30 times. Newly developing nations, such as China, generally have large wage disparities, thus increasing the importance of segmentation by income level and the creation of a marketing plan that sets specific targets.

In addition, market segmentation and targeting can be conducted using psychological variables such as lifestyle, and behavioral variables such as product usage. Geographical characteristics and population attributes can be understood using existing statistical data and figures from survey companies; however, companies must also conduct their own market research to understand consumers' 
psychological and behavioral variables. Rogers' diffusion model of innovation (Rogers 2007) is often used to classify consumer personalities. Sociologist Everett M. Rogers researched the diffusion process of new products and services and classified users into several groups in the following order of adoption: innovators (those who are first to adopt), early adopters, early majority, and laggards. There is a wide chasm between innovators and early adopters, and for high-tech products, crossing this chasm in marketing is crucial (Moore 2002). Thus, understanding the psychological attributes of target customers is critical when introducing innovative products into a market.

We now summarize the steps in marketing strategy. First, companies must collect market information and analyze it, by considering the strengths and weaknesses of their products, as well as the consistency of their products with market characteristics in light of relevant data. Companies should align their goals with a management strategy and direction for global businesses, as shown in the CAGE and AAA frameworks. Ansoff's product/market matrix is effective to match products and markets. In deciding whether to target new markets in line with the strengths of a company's products (market development), or to develop new products that meet local needs in global markets where the company already has business operations (diversification), companies must perform SWOT analysis that consider both internal management resources and external business environments. Creation of a marketing strategy is the goal of this step, and the strategy must be decided upon in the process of matching products and markets.

\subsection{Marketing, Planning, and Execution: The 4Ps}

The process of creating a specific marketing plan on the basis of a marketing strategy is referred to as the 4Ps of marketing. It includes product, price, place, and promotion, each of which is explained in the following paragraphs (Fig. 9.1).

The first element, product, includes a psychological value that consumers place on products that is derived from branding and design, in addition to the more direct value that is derived from functionality and performance. Among large consumer durables, delivery, installation, and other post-sales services should be thought of as part of product composition. Within target markets, companies must begin by developing basic concepts for products and services that most effectively meet customer needs. Next, they must design specific products not on the basis of function but on design and post-sales service. For example, Japanese consumer electronics products generally come with a warranty from the manufacturer, who agrees to repair the item free of charge within 1 year of purchase in case the item malfunctions for reasons that are not the fault of the user. Such a service is provided by the product's quality management. In contrast, China's consumer electronics giant Haier does not provide a warranty but has built competitive advantage by emphasizing post-sales services for its products. In the event of product malfunction, Haier deploys personnel to service the product within a few hours in case of the problem, instead of providing a warranty. In sum, companies must consider aspects such as post-sales 


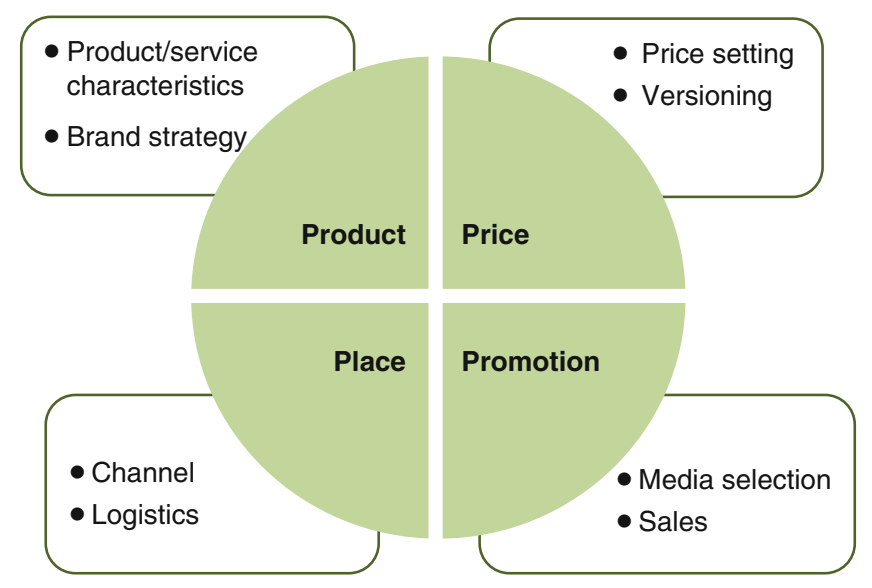

Fig.9.1 4Ps of Marketing

services in addition to product quality and functionality when developing their product concepts.

The brand is another item that can be put into product classification within marketing plans. Some brands are tied to company names, while others are tied to product names. The brand value of the former is in the company name itself, as in the case of Sony, which is known for its innovative products, or Toyota, which is known for its cars of high-quality. The latter is managed on a product-by-product basis. For example, the Procter \& Gamble $(\mathrm{P} \& \mathrm{G})$ categorizes its cosmetics business into the premium SKII brand and the mass market-oriented Olay brand. In the next chapter, we analyze Shiseido's marketing in China. It developed a brand of cosmetics called Aupres catering to the Chinese market, in addition to its global SHISEIDO brand. SHISEIDO brand cosmetics were exported to China and targeted the wealthiest consumers. The management at Shiseido therefore decided that it must develop new products that cater to a larger section of the market if they want to seriously expand in China. However, Shiseido decided to use a different brand name to market these new products, thereby downplaying the connection with Shiseido, as a measure to safeguard it against the potential risk of lowering the value of the SHISEIDO brand. This type of brand management is an important element in marketing planning.

The next element is price. The following aspects must be considered when determining the price of products and services:

- Cost of products and services

- Price elasticity in the market

- Prices of competitive products

Generating a profit by providing products and services requires that prices be set higher than costs. However, costs include both fixed costs, such as R\&D and asset depreciation, as well as variable costs, such as materials and manufacturing labor. 
In the case of fixed costs, the average cost of products and services decreases as the sales volume increases, making it necessary to estimate demand and be aware of when revenues will exceed average costs. Moreover, companies must have an understanding of the price elasticity of its products and services. Products with a high degree of price elasticity suffer from lagging sales as prices increase, making it difficult to increase the prices of such products. On the other hand, the demand for necessities does not change significantly even when prices increase. These products have low price elasticity and increasing their prices is relatively easy. Finally, in terms of the pricing of competitive products, if companies find it difficult to differentiate with competitive products on product quality, functionality, or post-sales service, they will also find it difficult to set prices higher than that of their competitors. For example, the recent price wars among manufacturers of flat-panel televisions have resulted in a considerable drop in the average sales price of these products. As a result, sales have grown; however, even the largest manufacturer, Samsung, has made almost no profit. Thus, when price wars occur among products that are largely similar, all vendors are forced to drop their prices to the bare minimum.

In addition, companies must think dynamically in terms of price strategies over a product's lifecycle. Price strategies for new products at the time of their introduction include "cream-skimming" and market penetration pricing. Cream-skimming refers to the strategy of setting prices at a high level to "skim" customers who do not mind paying premium prices (i.e., upper-class individuals with high reservation prices for products). For example, when Intel introduces new CPUs, it generally sets a high price for premium users (Ogawa 2009). In contrast, market penetration pricing sets the prices of new products on the low end. Products with network externalities influenced by a number of users have an incentive to draw a large number of users as quickly as possible. This phenomenon can be seen in the recent example of the standards competition in the high-end DVD market between the Blu-ray and HD-DVD formats.

There are various other strategies to set prices, such as creating various grades for one product, as in the case of automobiles; bundling complementary products, as in the case of mobile carriers that generate revenue through telecommunication fees while selling mobile phones at low cost; or versioning, where content is sold at different prices depending on the product release timing (e.g., releasing paperback versions of books after hardcover versions).

The third element is place, that is, the method of providing a product or service. Products developed by manufacturers need to reach customers by some means. Retailers provide these places and, depending on the product, they may also provide a complex distribution route that includes wholesalers. On the other hand, some companies provide products directly to consumers without going through a middleman (so-called disintermediation) via e-commerce over the Internet. "Place" relates to the channels that a company uses to deliver its products and services to customers.

When expanding a business into emerging countries such as China and India, dealing with these channels is a major issue. First, retailers or distributors, such as 
wholesalers, often face market-entry regulations imposed on foreign companies, which often require the partnership with a local company. For example, China joined the WTO in 2001, resulting in the elimination of most regulations for foreign retailers and wholesalers, with the exception of certain industry types. Large foreign supermarkets and convenience store chains are expanding into the Chinese market, though local companies still hold the major market share. India has more stringent regulations than China, and has delayed the entry of foreign firms into its market segments. Retailers in particular still face stringent regulations on foreign companies, and while there are some signs of deregulation, there are also political issues that make the prospects of dramatic improvements in the short term difficult. Accordingly, companies have found it necessary to build relationships with local companies and carefully manage these alliances. For example, Shiseido sells its products using specialty stores as its marketing strategy. In regional urban areas with no large-scale department stores, Shiseido has established superior quality cosmetics stores as specialty stores and trains beauty consultants in terms of personal sales. Shiseido has also established an incentive system that awards retailers with high sales volumes. Retailers can request to terminate their agreements with Shiseido at the time of agreement renewal, but most retailers opt for a long term agreement as Shiseido specialty stores.

Logistics, or the timely movement of products to a designated location, is another important element of "place." In India, fresh foods often go bad because of issues in logistics. Lagging infrastructure, such as roads and rail freight, is another major issue; however, the impact of inadequate skilled business logistics personnel in management, warehousing, and transportation optimization is prominent. Logistics services in India present a tremendous business opportunity, and many Japanese companies, including trading companies, are beginning to enter this domain. China and India are geographically vast, with typically high logistics costs. Therefore, making local logistics more efficient is critical.

The final P is "promotion," or sales promotion activities. Despite the selection of target markets that companies think will efficiently use their business resource strengths and develop products and services to match those markets, revenues do not increase without properly marketing them to customers. Sales promotions are held to effectively promote the process from capturing the attention of potential customers through a purchase. The behavioral patterns of consumers are explained below in the AIDMA steps:

Attention: the product captivates the attention of potential customers

Interest: they become interested in a product

Desire: they desire the product

Memory: their desire is no longer just a passing one, and the customer is seriously considering the product

Action: customers make the purchase

Potential buyers begin by focusing the targeted product. They may view a television commercial featuring the latest digital camera, and move on to the next step, in 
which the product makes an impression, whereby they become interested in the product. They then develop the desire to purchase the digital camera. However, even though they may want to purchase the product, it may be a passing one. Therefore, for a purchase, this desire must remain in the customer's memory. Finally, consumer behavior ends when the customer goes to a consumer electronics store and purchases the digital camera.

The means by which companies invest their efforts in promotions depend on the AIDMA process. In the first stages of gaining attention and interest, advertisements using videos or graphical images can be an effective way to create a product's impression. A variety of mass media, such as television commercials and newspaper and magazine advertisements, can be used to accomplish this. In addition, public relation (PR) activities centered on an event or word-of-mouth networks are also effective in the first half of the AIDMA process. Promotional tools include samples and gifts, product displays, pamphlets, or coupons. The human element, such as promotions involving salespeople in stores that provide advice to customers, is also important. Such promotions enable an engagement with customers that display a certain level of interest or desire for a particular product and are effective in the latter half of the AIDMA process.

However, the AIDMA model of consumer behavior has recently become obsolete and has morphed into the AISAS model: the first two aspects, "attention" and "interest," remain the same; however, the final three comprise "search," "action," and "share." The widespread use of the Internet is accompanied by greater use of e-commerce comparison sites. Moreover, consumers can easily purchase products over the Internet, thus shortening the process that begins by becoming interested in a product and ends with going to a store to make a purchase. Using our example of a digital camera, consumers first become interested in a product, search for it over the Internet, review its functions, and compare it with other products. They then purchase the product of their choice (the "action"), and share information about the product over the Internet by writing about it on blogs and social media such as Twitter. As word-of-mouth regarding the product begins to accumulate, it becomes an important source of information for the next potential purchaser.

The development of the Internet and social media has resulted in a downward trend in revenues from traditional mass media advertising sources of television and newspapers. On the other hand, Internet advertising revenues have grown because of the advantage of effectively reaching potential customers with a certain level of interest in the product by changing product advertising content based on search terms, as in the case of Google's keyword-based advertising services. The online environment in emerging countries such as China and India are no different than those in developed countries. Thus, the effectiveness of promotions using the rules of AISAS-based consumer behavior will only increase.

Note that the marketing methods discussed so far in this chapter do not apply to online markets. For example, recommendation techniques can be used in e-commerce on the basis of consumer keyword searches or purchasing history. Instead of market segmentation and targeting, companies can respond to individual consumer attributes on the Internet. Companies can use large volumes of data ("big data") 
available on the web to respond to consumer trends in real time; tracing consumer behavior patterns on the basis of this data is critical. In addition, companies must modify the 4Ps to market flexibly on the basis of the circumstances, rather than using the traditional method of creating marketing strategies systematically from marketing surveys. Marketing using big data is an advanced area, and the usage of the Internet has witnessed an increase even in emerging countries.

\subsection{Market Analysis Examples: China and India}

We use the examples of China and India in our discussion on marketing strategy creation. We do not analyze the details of marketing plans with specific products and services, but rather show the primary direction for strategy in these two emerging countries. The most important thing to consider for companies from advanced nations, including Japan, in terms of a business strategy in emerging countries is the difference in the economy between the home and target countries. An analysis of income levels and purchasing power of customers in target countries is important, particularly from the marketing perspective. However, data on average income levels in countries with great income disparities has little value. Information on household income distribution is important, and companies can use it to segment the market and consider the classes that should be targeted.

Figure 9.2 indicates the percentage of households in China and India with more than USD 10,000 in disposable income. These countries are experiencing rapid economic growth, and the number of households that purchase durable goods such

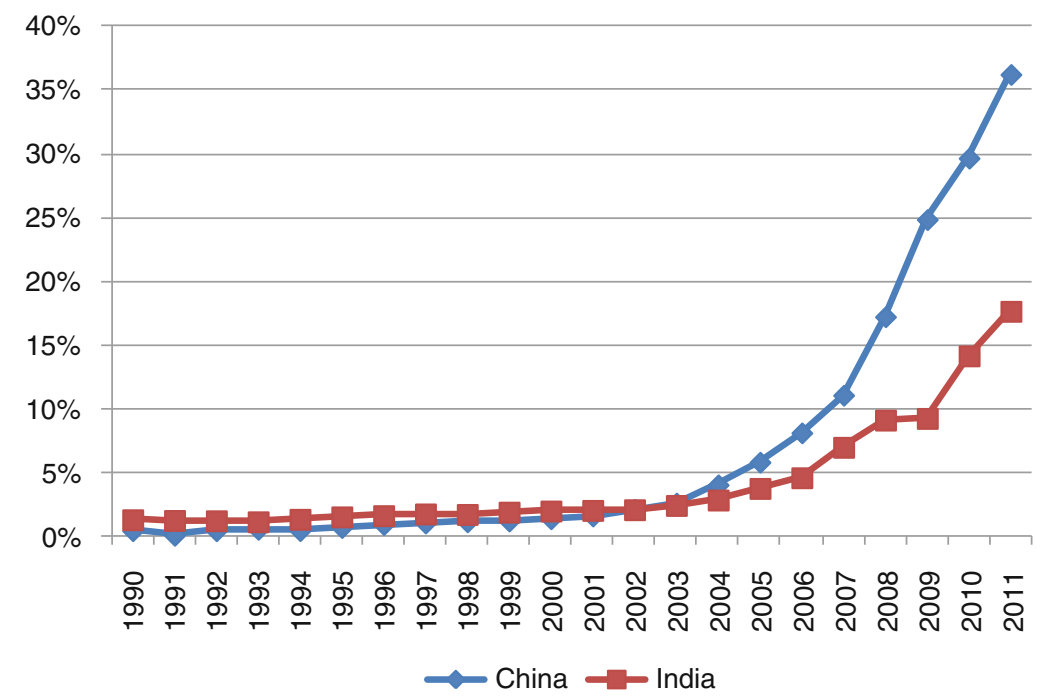

Fig. 9.2 Share of volume zone in China and India (Source: Author's estimates based on Euromonitor data) 
consumer electronics and cars, or those that take regular vacations is witnessing considerable growth. We have set USD 10,000 in disposable income for households as our delineator of the "volume zone." In the 1990s, 1-2 \% of households in both countries featured above this income line, and the numbers grew more rapidly after 2000. Growth in China was particularly significant, with more than $35 \%$ of households reporting more than USD 10,000 of income. However, this graph is in USD; therefore, we must discount for inflation.

Purchasing power parity (PPP) of consumers in both countries must be evaluated. It measures a country's purchasing power while adjusting for international price levels. For example, prices in Japan are relatively higher than those in China. Thus, on comparing household income levels in both countries, the purchasing power of households in China is, in real terms, greater than that in Japan. As of 2012, the purchasing power parity values of Japan, China, and India were 144, 53, and 44 (keeping that of the US at 100), respectively. In other words, while price levels in Japan are 1.44 times that of the US, those of China and India are is 0.53 and 0.44 times, respectively. This indicates that prices in Japan are approximately three times higher than those in China and India, thereby making the purchasing power of a Chinese household with USD 10,000 in annual income equivalent to a household earning USD 30,000 in Japan. However, note that purchasing power parity is a measure of the entire country's average. Products with large differences in domestic and international prices are daily necessities such as personal services or foodstuffs that are difficult to import from overseas; thus, the percentage of these products consumed by households with high income levels is low. On the other hand, goods such as automobiles and high-end consumer electronics have a marginal price disparity among Japan, China, and India. Therefore, companies must note that data income levels that are used to calculate the average purchasing power are too high to be considered in marketing strategies by advanced countries.

Figure 9.3 indicates the distribution of disposable income in Japan, China, and India to better understand the market environments in these countries. More than $70 \%$ of households in Japan have an annual disposable income of greater than USD 45,000, while the percentages in China and India are 3 and $1 \%$, respectively. Even when accounting for purchasing power, companies must recognize that the Chinese and Indian markets are very different from those in advanced countries. When Japanese companies expanding internationally to the US and European markets, the aspect of "aggregation" of the AAA framework was often used as a strategy. But premium markets, in which it is possible to use this strategy, comprise only a small portion of overall Chinese and Indian markets. However, as seen in Fig. 9.3, average income levels in China and India are rising at a rapid pace. Households above the quasi-advanced level of USD 25,000 in annual income are nearly $10 \%$ of the total households in China, and the total number of such households is approximately the same as that in Japan. In the next 5-10 years, it is likely that these countries will have premium markets as large as those in advanced nations.

However, in the shorter term, companies must analyze the strategies for targeting the middle classes below the volume zone. Among the assumptions of marketing strategies targeting this group, adaptation (for local markets) is required for 


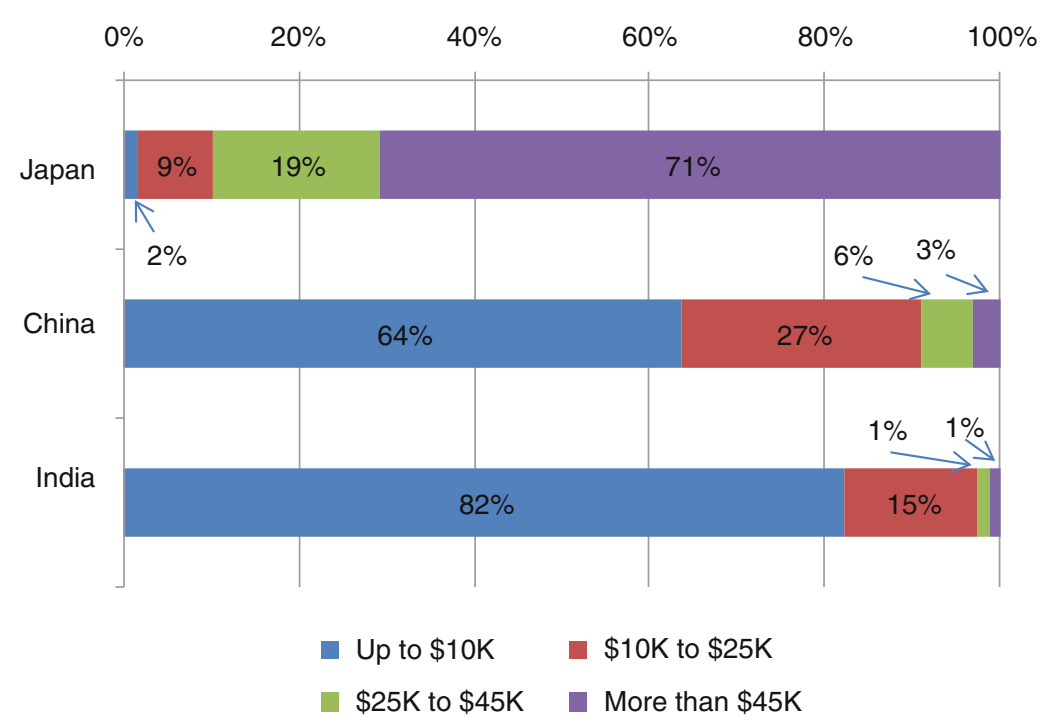

Fig. 9.3 Disposable income distribution in China and India (2011) (Source: Author's estimate based on Euromonitor data)

providing products that will be accepted in local markets with somewhat low income levels. Companies must, therefore, reduce the functionality and performance of products in order to sell them at a price which is lower than the price of the same product for domestic market. In addition, companies must review the entire value chain of a product, from materials procurement and the manufacturing processes, through distribution and post-sales service, in pursuing a low price model. Companies might have to form an alliance with a local company to improve their cost competitiveness.

The middle market offered by China and India is often termed as the "good enough market." When the pace of a product's technological innovation is rapid and a certain level of technology fulfills consumer demands, high-end products do not necessarily sell well even in premium markets with high-income levels. The innovator's dilemma causes destructive innovation, and when products become commoditized, the good enough market makes its appearance regardless of the income levels. According to an analysis of the Chinese television receiver market as of 2005, the shares of high-end market (dominated by foreign firms such as Sony and Panasonic), the mid-market (flat-panel televisions made by Chinese companies), and the low-end market (CRT televisions made by Chinese companies) were 13, 62, and $25 \%$, respectively, and the mid-market—a good enough market—was rapidly growing (Gadiesh et al. 2007). However, at the end of 2009, Sony introduced a lowcost LCD television into the Chinese market (a 32" model that sold for CNY 3,000), and by 2010 , the premium market had all but dried up. This example indicates that waiting for premium markets to take hold in emerging countries is not an effective strategy. 


\subsection{Is the Premium Market a Volume Zone?}

While companies from advanced countries may have high expectations for the premium markets in China and India, in which they do well, companies that have prioritized short-term profits must undertake an adaptation strategy for local markets by targeting the volume zone of the middle-class. Industries that easily fall prey to the innovator's dilemma because of a high rate of technological innovation cannot have any expectations of a premium market and must, instead, pursue the good enough market. Should a company prioritize the premium market, or should it take the low-price path to succeed in an emerging country? This question is important in determining a global strategy.

These strategy options can be summarized by customer needs in the target market and technology competition in the local market (Gadiesh et al. 2007). In terms of customer needs, companies must ascertain whether the demand for a product's performance or quality has risen or whether the specifications of high-end products are too high for the market to absorb. In case of growing demands to improve product performance, there may be room for differentiation with local products in terms of performance and quality by companies from advanced countries. However, if that is not the case, then lower costing local products are sufficient for the market. Therefore, there are no incentives to purchase high-cost, high-function products, and there is a high likelihood of becoming involved in a price war with local companies. In addition, in terms of technological competition, the strategies undertaken by companies from advanced countries will vary with the size of the gap separating them and local companies (Table 9.3).

First, we consider cases in which there exist customer requirements for product quality and functionality. Business-to-business (B2B) products such as highperformance materials used in automotive parts, industrial equipment, and construction equipment for the most part fit this category. Customers have an incentive to constantly improve productivity, thus creating high demands for performance and quality. In addition, durable consumer goods, such as cars and air conditioners, often fit this category. Because these products are often used over an extended

Table 9.3 Matrix analysis of customer needs and technology competitiveness

\begin{tabular}{l|l|l}
\hline $\begin{array}{l}\text { Technological } \\
\text { competitiveness }\end{array}$ & Customer needs & \multicolumn{2}{|l}{$\begin{array}{l}\text { Product performance >Customer } \\
\text { needs } \\
\text { needs } \\
\text { Enables the differentiation of } \\
\text { performance and quality } \\
\text { of performance and quality }\end{array}$} \\
\hline $\begin{array}{l}\text { Large gap with } \\
\text { local companies }\end{array}$ & $\begin{array}{l}\text { High-quality, high-cost strategy } \\
\text { (expect expansion of premium } \\
\text { market) }\end{array}$ & $\begin{array}{l}\text { Good enough quality, low-cost } \\
\text { strategy, partnerships with local } \\
\text { companies }\end{array}$ \\
\hline $\begin{array}{l}\text { Local companies } \\
\text { play catch up }\end{array}$ & $\begin{array}{l}\text { Strategy of using R\&D } \\
\text { investment to slow down catch up }\end{array}$ & $\begin{array}{l}\text { Acquisition of local companies, } \\
\text { management localization }\end{array}$ \\
\hline
\end{tabular}

Source: Adapted from Gadiesh et al. (2007), p. 85 
period, customers often demand energy-saving features and high quality. Cases in which there is a large technological gap between entering and local companies in terms of consumer durables, strategies that target premium markets with highquality, high-function products are reasonable. On the other hand, companies must plan to differentiate products that local companies can technologically catch up with, and those that are easily prone to price wars. Companies must plan to shift away from the stand-alone product model explained in Chap. 5 and move to a customer value model, thereby building an operating model that will make it difficult for local companies to catch up.

Next, companies must seriously consider a low price strategy for good enough markets in industries where they face difficult competition against cheap local products and where customer demands for product functionality and quality are fully satisfied. As seen in China's television market, electronics products fit this category because of their high rate of technological innovation. Even in this case, a company must respond differently depending on the size of the technological gap between it and local companies. If a company is technologically superior and cannot be easily imitated by local companies, it can, to a certain extent, differentiate its products from low price local products on functionality and quality. However, since companies must provide products at a lower price than markets in the home country, they must develop products for the local market that have only the functionality and level of quality that customers there need. In addition, it is necessary that companies make the value chain of suppliers, manufacturing processes, and distribution channels more efficient to cut costs, and realize a low-cost model that depends on alliances with local companies in many areas. On the other hand, companies find it difficult to respond to markets where customers' product needs are satisfied, and more so when those products are made by companies in emerging countries that are already technologically on par. Companies cannot differentiate their products on technology in such a case, and must instead compete directly in terms of price. Considering that the headquarters head the company from advanced nations, competing in terms of price with local companies will be difficult unless that company has a high level of productivity. Thus, companies may opt to acquire a local company and make the management more efficient, but they will need to create a management structure on the basis of local personnel to avoid the rising operating costs.

Should companies in advanced countries opt for a low price strategy in good enough markets within emerging countries, they must be careful not to fall prey to cannibalization of their high-end products made for premium markets. Manufacturers such as Sony and Panasonic have a brand image that conveys quality and performance. They therefore need to make marketing plans for quality levels, prices, distribution channels, and other areas such that their brand value is not damaged when competing in terms of price. Shiseido ensures that cannibalization does not occur through brand management, using the global SHISEIDO brand made for premium markets and the Aupres brand for products in the Chinese market. This point should be noted by companies pursuing a low price strategy where they already have some history of selling to premium markets. 


\subsection{The Bottom of the Pyramid Business}

As mentioned earlier, BOP signifies the lowest level in the income class distribution pyramid. Of the global population of approximately six billion people, two-thirds or four billion live on only a few dollars a day. The BOP business derives profit from these poorer classes, but at the same time, it involves the people in these lower classes in the process of operating this business by providing opportunities to participate in society to those who otherwise have no stable employment. In addition, some companies have businesses that aim to improve the living conditions of those who struggle with poor nutrition or sanitation; they often partner with international organizations or NGOs that are working on poverty issues. Companies expanding their global business are expected to contribute to society through work on environmental issues or in other areas. Global corporations face the growing need of balancing their traditional for-profit businesses with non-profit activities, and thus can gain some important suggestions from the BOP business model.

The BOP model does not merely comprise activities that contribute to society. A business must generate profits, therefore requiring companies to understand from where value is derived. Simply put, a value added is created by eliminating the "poverty penalty" of the poor who live in conditions without a reliable social system or business environment. For example, in Mumbai, India, there is a large slum area called Dharavi, as well as a wealthy neighborhood called Warden Road. The book Next Market (Prahalad 2005) compares no collateral consumer financing for both of these areas and notes that whereas annual interest rates in wealthy neighborhoods are $12-18 \%$, they are 600-1,000\% in the slums. Similarly, the book compares prices for water, telephone, diarrhea medicine, and rice, and observes that all of these prices are higher in the slums, where a "poverty penalty" is imposed. Highquality public utility services are not provided in slum areas, and higher credit risks imply higher service fees. If some sort of system can be implemented to enable credit transactions in these areas, new businesses can be established to promote value creation.

Microfinance is an example of a business system that reduces the poverty penalty in financial services. In such a system, locals become bankers and provide small loans. Borrowers use this funding to finance small businesses such as shops or individual services, thereby contributing to the creation of new businesses in that region. Key to this service are the reduction in credit risk whereby local citizenry become bankers as well as a personal relationship with borrowers. Bankers receive income from the interest generated when loans are paid back, creating incentives for the lenders to make loans corresponding to their ability to repay. Having many locals acting as bankers reduces the risk of bad debt, and the system generates a profit from the low interest. The system of microfinance is relatively simple, and though it began in Bangladesh through Muhammad Yunus and his Grameen Bank, it has since spread to countless operations in India as well as across the African continent. It has been accompanied by criticism as well, owing to the unreasonable amount of 
profit made by some banks by charging high interest rates, and the accumulation of excess debt by some borrowers, thereby becoming unable to repay their loans.

Marketing costs can become an entry barrier for manufacturers wanting to expand to a BOP business. First, a solid business cannot be built around BOP without products that have the prospect of a certain amount of demand from the poor who make up the target market. These people often live in limited communities, making it difficult for companies to understand market needs. In addition, many people are simply living day to day, causing large fluctuations in demand. Furthermore, creating distribution channels to deliver products to customers entails exorbitant costs. In such a business, where low-priced products are sold in large volumes, high demand volatility can be fatal. Thus, partnering with various players is ideal for running a successful BOP business. For example, market needs of the poor can be obtained from detailed information held by NGOs that provide local assistance. Product distribution can be built through tie-ups with banks that provide microfinance and by leveraging the local banker network.

Hindustan Unilever (the Indian subsidiary of the European CPG manufacturer Unilever) formed alliances with multiple parties to create a successful soap business in India. It first launched a global public-private partnership (PPP) to promote the idea of washing hands with soap to improve hygiene in India. It held promotional activities to instill the custom of using soap when washing hands in conjunction with the World Bank and USAID. In the process, it partnered with approximately 400 NGOs and conducted local seminars on how to use soap. It employed saleswomen in rural areas referred to as shakti, who educated locals on hygiene and offered advice in addition to selling products. The company led with the societal goal of improving rural hygiene and was successful in generating royalties and creating a brand image for its products.

Several Japanese companies have also begun similar efforts, such as Ajinomoto's nutrition improvement program in Ghana. However, only a few companies have been successful in BOP businesses. P\&G invested USD ten million worldwide in a project to sell a powder that cleans water, but later realized the difficulty of generating profits from the sale of the product and instead turned it into a philanthropic enterprise (Karamchandani et al. 2011). BOP businesses benefit society by solving poverty issues that invigorate rural areas or improve nutrition and hygiene; however, companies must balance these efforts by actually creating a profitable business. BOP businesses require the creation of ecosystems that involve a broad range of players, from public organizations for developmental assistance and NGOs to local communities. Thus, companies that run these businesses must first understand the objectives of each organization they work with, and then act as coordinators in winwin joint efforts.

\subsection{Conclusion}

In this chapter, we discussed methodologies for the planning and execution of marketing strategies, and examined case studies targeting China and India. Global aggregation strategies are often not effective for companies in advanced countries, 
including those in Japan, which attempt to expand their home country business into global markets. Business environments and customer needs are often markedly different in target countries, thereby requiring companies to deepen their understanding of these markets. Large countries such as China and India have great income disparities, wherein wealthy classes have lifestyles on par with those in advanced countries, while poor classes make less than USD 1,000 per year. Because of the various customer classes due to differences in regional characteristics and lifestyle, market segmentation and targeting of specific customers become important. Therefore, companies can choose marketing plans according to the 4Ps: developing a product according to local circumstances; setting a price; arranging distribution channels for products and services (i.e., place); and implementing promotions that provide product information to potential customers.

In this chapter's case studies, we examined the high-growth trends in the middle class - the volume zone-in terms of the hierarchical distribution of disposable income. Households with disposable income greater than USD 10,000 have been increasing rapidly in both China and India since 2000, and as of 2011 they have accounted for 36 and $15 \%$, respectively, of their overall national markets. However, a large gap still exists between these countries and Japan, where most households have above USD 45,000 in disposable income. Thus, acquiring customers from the middle classes of both countries requires a low price strategy.

However, companies in advanced countries effectively target wealthy classes that are similar to markets in their home country; therefore, they must carefully consider whether to pursue a low price strategy for a good enough market. In this chapter, we introduced a matrix to analyze customer needs and competitive environments with local companies, as a framework to determine strategic options. There are few incentives to purchase high-priced, high function products even for the wealthy, when the ascending curve of customer needs for product functionality and performance is somewhat satisfied. In such a case, companies must select a low price strategy for good enough markets. However, if companies possess technology superior to that of their local competitors, they can partner with local companies using their technology as leverage. Should companies find it difficult to differentiate products because of technological catch up by local competitors, their only hope of success is to beat their competitors in terms of prices. Accordingly, companies may also have the option of continuing operations without major changes by acquiring a local company. On the other hand, in case of an increase in the demand for product functionality and performance, it is possible to pursue the premium market using a high price/high function strategy if the company has superior technology. To avoid the quick catch up of local competitors in terms of technology, a company can invest in $R \& D$ or build a business model that makes catch up difficult.

We conclude this chapter by discussing the BOP business that targets the bottommost classes of the world's population. Companies taking this path must operate their business with a proper balance of for-profit and non-profit activities, combining the business with social contribution objectives such as solving poverty issues or improving nutrition and hygiene. There are few success stories in the BOP market; however, the value of providing services required by the poverty-stricken is large because companies partner with a broad range of stakeholders such as public 
organizations that provide developmental aid, NGOs, and local communities. Companies conducting business globally will find it worthwhile to consider this business model in some form.

Open Access This chapter is distributed under the terms of the Creative Commons Attribution Noncommercial License, which permits any noncommercial use, distribution, and reproduction in any medium, provided the original author(s) and source are credited.

\section{References}

Diamond Inc. (2002). MBA management book. Tokyo: Diamond Inc.

Gadiesh, O., Leung, P., \& Vestring, T. (2007). The battle for China's good-enough market. Harvard Business Review, 85, 80-89.

Karamchandani, A., Kubzansky, M., \& Lalwani, N. (2011). Is the bottom of the pyramid really for you? Harvard Business Review, 89, 107-111.

Moore, J. (2002, January). Chasm (trans: Kawamata Seiji). Tokyo: Shoeisha.

Ogawa, K. (2009, July). Management text marketing Nyuumon. Tokyo: Nikkei Sangyo Shinbunsha.

Prahalad, C. K. (2005, December). Next market "Hinkonsou" wo "Koukyaku" ni Kaeru Jisedai Business Senryaku (Wharton Keiei Senryaku Series) (trans: Skylight Consulting). Tokyo: Nikkei BP.

Rogers, E. M. (2007). Innovation Fukyuugaku (trans: Aoike Shin'ichi \& Uno Yoshiyasu). Tokyo: Sanno Daigaku Shuppanbu. 